\title{
AReview \\ Scope and future perspectives of phytoremediation
}

\author{
Sridevi Tallapragada, Rajesh Lather, Vandana and Gurnam Singh
}

\begin{abstract}
SUMMARY
Phytoremediation is the plant-based technology that has emerged as a novel cost effective and ecofriendly technology in which green plants are used for extraction, sequestration and/or detoxification of the pollutants. Plants possess the natural ability to degrade heavy metals and this property of plants to detoxify contaminants can be used by genetic engineering approach. Currently, the quality of soil and water has degraded considerably due heavy metal accumulation through discharge of industrial, agricultural and domestic waste. Heavy metal pollution is a global concern and a major health threat worldwide. They are toxic, and can damage living organisms even at low concentrations and tend to accumulate in the food chain. The most common heavy metal contaminants are: $\mathrm{As}, \mathrm{Cd}, \mathrm{Cr}, \mathrm{Cu}, \mathrm{Hg}, \mathrm{Pb}$ and $\mathrm{Zn}$. High levels of metals in soil can be phytotoxic, leading to poor plant growth and soil cover due to metal toxicity and can lead to metal mobilization in runoff water and thus have a negative impact on the whole ecosystem. Phytoremediation is a green strategy that uses hyperaccumulator plants and their rhizospheric micro-organisms to stabilize, transfer or degrade pollutants in soil, water and environment. Mechanisms used to remediate contaminated soil includes phytoextraction, phytostabilization, phytotransformation, phytostimulation, phytovolatilization and rhizofiltration. Traditional phytoremediation method presents some limitations regarding their applications at large scale, so the application of genetic engineering approaches such as transgenic transformation, nanoparticles addition and phytoremediation assisted with phytohormones, plant growth-promoting bacteria and Arbuscular mycorrhizal fungi (AMF) inoculation has been applied to ameliorate the efficacy of plants for heavy metals decontamination. In this review, some recent innovative technologies for improving phytoremediation and heavy metals toxicity and their depollution procedures are highlighted.
\end{abstract}

Key Words : Decontamination, Hyper-accumulator plants, Heavy metals, Phytoremediation

How to cite this article : Tallapragada, Sridevi, Lather, Rajesh, Vandana and Singh, Gurnam(2021). Scope and future perspectives of phytoremediation. Internat. J. Plant Sci., 16 (AAEBSSD): 77-85, DOI: 10.15740/HAS/IJPS/16.AAEBSSD/77-85, Copyright@ 2021: Hind Agri-Horticultural Society.

Article chronicle : Received : 06.07.2021; Accepted : 15.07.2021

MEMBERS OF THE RESEARCH FORUM

Author to be contacted :

Sridevi Tallapragada, C.C.S. Haryana Agricultural University, Hisar (Haryana) India

Email : stallapragada21@gmail.com

Address of the Co-authors:

Rajesh Lather, Vandana and Gurnam Singh,C.C.S. Haryana Agricultural University, Hisar (Haryana) India
$\mathrm{T}$ he quality of soil is degraded day by day due to the complications associated with heavy metal pollution. Heavy metal pollution is of global concern and a major health threat worldwide. Approximately 300 years ago the technology Phytoremediation was used for the treatment of waste water (Hartman, 1975). Baumann in the year 1885, firstly 
documented two plant species, viz., Thlaspi caerulescens and Viola calaminaria, which accumulate high concentrations of heavy metals in leaves. Byers, 1935 analysed the dry shoot biomass of the genus Astragalus and findings revealed that it has the capacity to accumulate selenium (Se) concentration up to $0.6 \%$. Then in 1948, more plants were identified as accommodating Nickel (Ni) concentration up to the level of 1\% (Minguzzi and Vergnano, 1948). Rascio, 1977 reported Thlaspi caerulescens possesses a high resistance to $\mathrm{Zn}$ and accumulates high $\mathrm{Zn}$ concentration in its shoots. Phytoremediation is a green strategy that uses hyperaccumulator plants and their rhizospheric microorganisms to stabilize, transfer or degrade pollutants in soil, water and environment (Liu S. et al.,2020) This technology is considered as well-efficient, cheap and adaptable with the environment (Nedjimi, 2020). According to the soil conditions, pollutant and the species of plants used, five types of phytoremediation have been applied: phytodegradation, Phytofiltration, phytoextraction, phytostabilization and phytovolatilization. Plants were classified to be tolerant and/or hyperaccumulator to Heavy Metals (HMs) when they show rapid growth, high biomass and are capable to extract and accumulate high amounts of HMs in their shoots, without signs of toxicity when grown in contaminated soils (Table 1). Hence this green technology can be very useful for remediation of HMs contaminated soils/agro-ecosystems. Plant hyper-accumulators have received greater attention in recent decades, due to its potential to $\mathrm{HMs}$ contamination. However, there are some limitations for these plants to become efficient at large scale. These limitations need to be overcome by transgenic approach applications to improve HMs tolerance/accumulation of these plants (Rai et al., 2020). This critical review describes the effective mechanisms of phytoremediation, the promising potential of hyperaccumulator plants and the biotechnological approach for HMs decontamination.

\begin{tabular}{|c|c|c|c|}
\hline Sr. No. & Species & Heavy metals & Reference \\
\hline 1. & Acacia nilotica & $\mathrm{Cd}$ & Shabir et al. (2018) \\
\hline 2. & Atriplex lentiformis & $\mathrm{Cd}$ & Eissa and Abeed (2019) \\
\hline 3. & Boehmeria nivea & $\mathrm{Cd}$ & Pan et al. (2019) \\
\hline 4. & Canna indica & $\mathrm{Cd}$ & Solanki et al. (2018) \\
\hline 5. & Lagerstroemia indica & $\mathrm{Cd}$ & Wang et al. (2016) \\
\hline 6. & Atriplex halimus & $\mathrm{Zn}$ & Lutts et al. (2004) \\
\hline 7. & Brassica Juncea & As & Ko et al. (2008) \\
\hline 8. & Pteris vittata & As & Wang et al. (2002) \\
\hline 9. & Berkheya coddii & $\mathrm{Ni}$ & Robinson et al. (1997) \\
\hline 10. & Salix viminalis & $\mathrm{Ni}$ & Korzeniowska and Stanislawska-Glubiak (2019) \\
\hline 11. & Genipa americana & $\mathrm{Cr}$ & Santana et al. (2012) \\
\hline 12. & Pistia sp. & $\mathrm{Cr}$ & Mondal and Nayek (2020) \\
\hline 13. & Dalbergia sissoo & $\mathrm{Cu} / \mathrm{Ni}$ & Kalamet al. (2019) \\
\hline 14. & Helianthus annuus & $\mathrm{Cu} / \mathrm{Pb}$ & Forte and Mutiti (2017) \\
\hline 15. & Hydrocotyle ranunculoides & $\mathrm{Cu} / \mathrm{Zn}$ & Demarco et al. (201 8) \\
\hline 16. & Lathyrus sativus & $\mathrm{Cd} / \mathrm{Pb}$ & Abdelkrim et al. (2019) \\
\hline 17. & Ludwigia peploides & $\mathrm{Pb} / \mathrm{Zn}$ & Fernandez San Juan et al. (2018) \\
\hline 18. & Noccaea caerulescens & $\mathrm{Zn} / \mathrm{Cd} / \mathrm{Ni}$ & Kozhevnikova et al. (2020) \\
\hline 19. & Spartina $s p$. & $\mathrm{Hg}$ & Tian et al. (2004) \\
\hline 20. & Suaeda fruticose & $\mathrm{Cd} / \mathrm{Cu}$ & Bankaji et al. (2015) \\
\hline 21. & Thlaspi caerulescens & $\mathrm{Zn} / \mathrm{Pb} / \mathrm{Cd}$ & Banasova et al. (2008) \\
\hline 22. & Usnea amblyoclada & $\mathrm{Pb}$ & Carreras et al. (2005) \\
\hline 23. & Haumaniastrum robertii & Co & Kabeya et al. (2018) \\
\hline 24. & Vetiveria zizanioides & $\mathrm{Cd} / \mathrm{Cu}$ & Kumar et al. (2018) \\
\hline 25. & Solanum nigrum & $\mathrm{Cd}$ & Wei et al. (2013) \\
\hline
\end{tabular}


Last, some recent innovative technologies for improving phytoremediation and future prospects like over expression of foreign genes in non-tolerant plants, nanoparticles (NPs) addition and phytoremediation assisted with phytohormones, microbial and AMF inoculation are presented. Finally, it should be kept in mind that phytoremediation is an interdisciplinary area of research where plant biology, microbiology, soil science, genetic engineering and environmental modelling converge. In addition, there is a novel phenomenon known as phytomining, one of the aspects of green technology that utilizes metal-hyperaccumulating plant species to extract metal ores generally termed as bio-ore from soil.

\section{Phytoremediation techniques:}

For removal of different hazardous compounds from contaminated soil and water, plant potentials have been exploited that resulted in several technological subsets (Fig. 1). Schwitzguebel (2000) has defined the following techniques: Phytoextraction is the use of pollutant accumulating plants to remove pollutants like metal organics from soil by concentrating them in harvestable plant parts. Phytostabilization is the use of plants to reduce the mobility and bioavailability of pollutants in the environment, thus preventing their migration to groundwater or their entry into the food chain. Phytotransformation is the degradation of complex

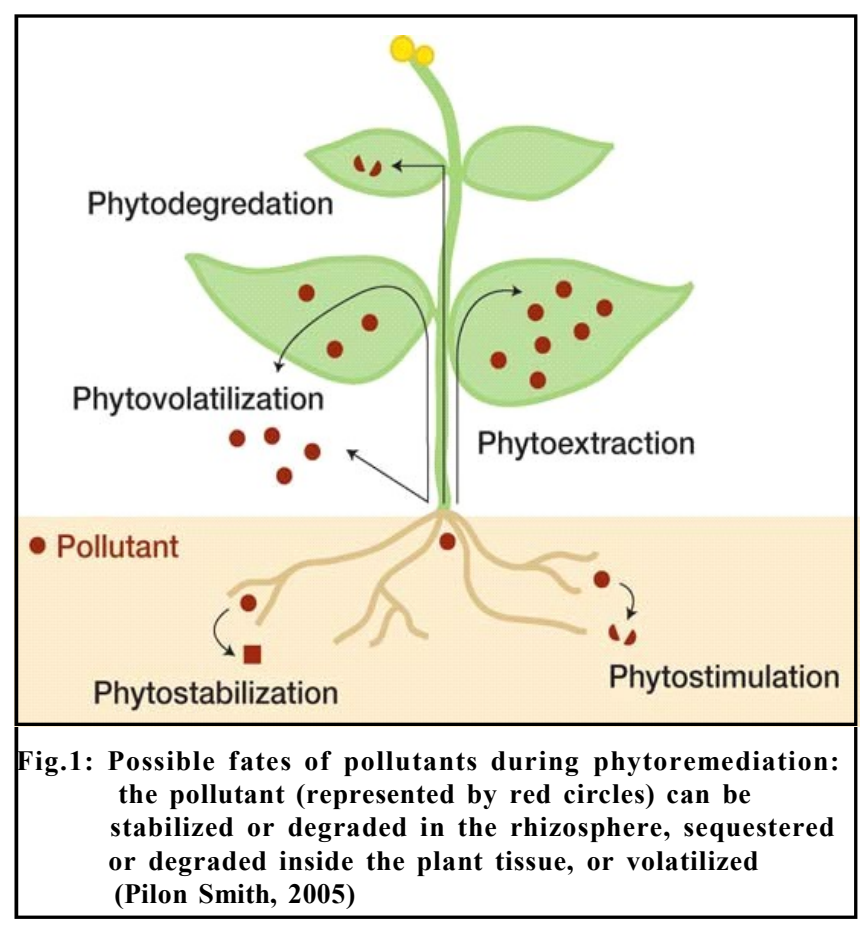

organic to simple molecules or the incorporation of these molecules into plants tissues (Fig.3). Phytostimulation is plant-assisted bioremediation or the stimulation of microbial and fungal degradation by release of exudates/ enzymes into the root zone (rhizosphere). Phytovolatilization is the use of plants to volatilize pollutants or metabolites. Phytodegradation is enzymatic breakdown of organic pollutants such as trichloroethylene (TCE) and herbicides, both internally and externally and through secreted plant enzymes. Rhizofiltration is the use of plant roots to ab/adsorb pollutants, mainly metals, but also organic pollutants, from water and aqueous waste streams. Dendroremediation is the use of trees to evaporate water and thus to extract pollutants from the soil.

\section{Limitations of phytoremediation:}

Phytoremediation offers a low-cost, low maintenance, environment-friendly and renewable resource for the remediation of contaminated environments. In some situations, for example pesticideladen soil or ground water, phytoremediation may be the only practical and economical in situ technique that can be used to remove pollutant chemicals. However, phytoremediation has its own limitations. The uptake and translocation of organic pollutants from soil through the plant root may be limited to compounds that are not highly hydrophobic, and through foliage to compounds that are not hydrophilic. Also, the technology would probably have little impact in situations where low levels of a pesticide were widely distributed in the environment. Even when large amounts of pesticides were present in a given environmental compartment, such as soil or water, phytoremediation could at best be useful as a long-term strategy. This is because plant growth is dependent on a number of environmental and climatic factors, availability of water and nutrients, soil type and $\mathrm{pH}$, etc. Even under the most favourable conditions, plant growth and removal/ degradation of pesticides may not exceed a certain rate. These limitations require integration of phytoremediation with other more immediate clean up options, as well as more economical utilisation of the biomass produced for non-food purposes, for example energy generation. However, the role of vegetation and plant biomass as an absorbent and a long-term sink for diffused pesticides must not be underestimated. There is also a need for finding ways to enhance the absorption and degradation of pesticides in plants. As microbial activity in the 
rhizosphere is known to aid the release of bound pesticide residues in soil, which can enhance uptake and transformation by plants, a combination of microbial bioremediation and phytoremediation is likely to be more successful in the field. Whilst the advancement in biotechnological sciences has revolutionised a number of areas of conventional science, this has had a little impact on phytoremediation until now. The amount of knowledge generated in plant biotechnology in recent years is enormous, and there are many more yet unexplored avenues that can be pursued to engineer or enhance a particular pathway for the phytodegradation of persistent pesticides in the environment.

\section{Technologies for improving phytoremediation:}

The selected plant species with phytoremediation potential have few limitations, such as slow growing, which limit rapid and large-scale applications of these plants (Sarwar et al., 2017) and adaptation to a variety of environmental conditions like nutrient-poor soils (Gerhardt et al., 2017). Hence, to minimize these limitations, a strategy is developed through modifying and improving certain traits of these plants to ensure their ability for effective phytoremediation. Traditional breeding (plant hybridization) or genetic engineering (creation of transgenic plants) are employed to either improve growth rate and biomass of hyperaccumulator or introduce hyperaccumulation traits to fast growth, high biomass plants (DalCorso et al., 2019). Brewer et al. (1999) used electrofusion to fuse protoplasts isolated from the $\mathrm{Zn}$ hyperaccumulator T. caerulescens and Brassica napus. The selected somatic hybrids which have enhanced hyperaccumulation capability and tolerance derived from $T$. caerulescens and higher biomass production derived from B. napus (Brewer et al., 1999), showed the ability to accumulate high levels of $\mathrm{Zn}$ and $\mathrm{Cd}$. This study indicated that transfer of the metal hyperaccumulation trait to high biomass plants is feasible through somatic hybridization. Similarly, Nehnevajova et al. (2007) used chemical mutagen ethyl methanesulfonate (EMS) to treat sunflowers and obtained sunflower "giant mutant," which exhibited a significantly enhanced heavy metal extraction ability with 7.5 times accumulation for $\mathrm{Cd}, 9.2$ times for $\mathrm{Zn}$, and 8.2 times for $\mathrm{Pb}$ compared to control plants (Nehnevajova et al., 2007).

Genetic engineering has been proved as a promising technique for improving phytoremediation abilities of plants toward heavy metal pollution. As compared to the traditional breeding, genetic engineering has the advantages to modify plants with desirable traits for phytoremediation in a much shorter time. Moreover, genetic engineering can even transfer desirable genes from hyperaccumulator to sexually incompatible plant species, which is impossible to achieve through traditional breeding methods such as crossing (Berken et al., 2002; Marques et al., 2009). Therefore, using genetic engineering to develop transgenic plants with the desired traits has shown attractive prospects in the field of phytoremediation (Fig.2). Technically, modifying fastgrowing, high-biomass species to obtain high tolerance and high heavy metal accumulation ability is more applicable than engineering hyperaccumulators to get high-biomass production. Hence, in most applications, fast-growing, high-biomass plants are engineered either to enhance tolerance against heavy metals or to increase heavy metal-accumulation ability, which are the key properties of hyperaccumulators. Therefore, the selection of genes for genetic engineering should base on the knowledge of heavy metal tolerance and accumulation mechanisms in plants. Heavy metals may cause excessive production of ROS and result in oxidative stress, so heavy metal tolerance is usually manifested by the strength of oxidative stress defense system. Therefore, the most common strategy to increase heavy metal tolerance is to enhance antioxidant activity (Koz'min'ska et al., 2018), which can be achieved by overexpression of genes involved in antioxidant machinery. To increase heavy metal accumulation through genetic engineering, the common strategy is to introduce and overexpress genes that are involved in the uptake, translocation and sequestration of heavy metals (Mani and Kumar, 2014; Das et al., 2016). Hence, genes encoding heavy metal/metalloid transporters can be transferred and overexpressed in target plants to improve heavy metal accumulation. These genes encode metal ion transporters including ZIP, MTP, MATE and HMA. As metal chelators act as metal- binding ligands to improve heavy metal bioavailability, promote heavy metal uptake and root-to-shoot translocation as well as mediate intracellular sequestration of heavy metal ions in organelles, it is a promising strategy to increasing heavy metal accumulation by promoting the production of metal chelators via genetic engineering. By overexpression of genes encoding natural chelators, heavy metal uptake and translocation can be improved (Wu et al., 2010).

Although genetic engineering approach has shown attractive prospects on improving plant performance in phytoremediation of heavy metals, there are also a few 
setbacks that remain.As the mechanisms of detoxification and accumulation of heavy metals are very complicated and involve a number of genes, genetic manipulation of multiple genes to improve desired traits is time and effort consuming and usually not successful. Another issue is that genetically modified plants are difficult to gain approval for field testing in some areas of the world due to the risk raised on food and ecosystem safety. Therefore, alternative approaches are required to improve plant performance in phytoextraction once genetic engineering is impracticable. Another best alternative is using micro-organisms to improve plant performance.

Use of plant-associated microorganisms (rhizosperic microorganisms) is another approach to improve plant performance for phytoremediation. The microbial community of the rhizosphere may directly stimulate root proliferation and, thus, promote plant growth, increase heavy metal tolerance and plant fitness (Gupta et al., 2013a; Fasani et al., 2018). It has been shown that plant growth-promoting rhizobacteria (PGPR) have large potential to improve phytoremediation efficiency. PGPR can promote plant growth and fitness, protect plants against pathogens, increase plant tolerance to heavy metals, improve plant nutrient uptake as well as heavy metal uptake, and translocation (Ma et al., 2011). This is achieved by producing various compounds, such as organic acids, siderophores, antibiotics, enzymes, and phytohormones (Ma et al., 2011). PGPR can synthesize the 1-aminocyclopropane-1-carboxylate (ACC) deaminase, which degrades the ethylene precursor ACC. Through producing ACC deaminase, PGPR is able to lower ethylene production, thus, promote plant growth (Arshad et al., 2007; Glick, 2014). Plants inoculated with PGPR containing ACC deaminase showed enhanced biomass production as manifested by extensive root and shoot densities, resulting in enhanced uptake of heavy metals and increased phytoremediation efficiency (Huang et al., 2004; Arshad et al., 2007). PGPR can also produce bacterial auxin (IAA) to stimulate lateral root initiation and root hair development, thus promoting plant growth and facilitating phytoremediation (Glick, 2010; Dal Corso et al.,2019). Ji et al. (77) revealed that application of 10, 100 and $1000 \mathrm{mgL}^{-1}$ gibberellic acid 3 $\left(\mathrm{GA}_{3}\right)$ can significantly increase biomass and phytoremediation efciency of Solanum nigrum. Recently Song et al. (180) demonstrated that the growth enhancement efect of supplemental ABA on Zn-stressed Vitis vinifera was due to the expression of ZIP and detoxifcation-related genes. Similarly, Leng et al. (102) found that supplementation of 5, 10 and $15 \mu \mathrm{m}$ ABA alleviates adverse efects of $\mathrm{Cd}$ on the growth of mung bean (Vigna radiate) plants. Arbuscular mycorrhizal fungi (AMF) are another important microbial community that can assist plants for phytoremediation. The presence of AMF in rhizospheres increases the absorptive surface area of plant roots through the extensive hyphal network, thus, enhancing water and nutrient uptake as well as heavy metal bioavailability (Göhre and Paszkowski, 2006). AMF can also produce phytohormones to promote plant growth and aid phytoremediation (Vamerali et al., 2010).

Earthworms known as 'ecosystem engineers' are the main group of soil macroinvertebrates. They play a vital role in organic matter decomposition, nutrient cycling and ameliorant of soil conditions. Wang et al. (2002) demonstrated that integration of earthworms in culture medium enhances the phytoremediation capacity of $\mathrm{Cd}$ in Solanum nigrum. Bongoua-Devisme et al. revealed that Pontoscolex corethrurus can alleviate $\mathrm{Cr}$ and $\mathrm{Ni}$

\begin{tabular}{|c|c|c|c|c|}
\hline Sr. No. & Name of bacteria & Host species & Heavy metals & References \\
\hline 1. & Arthrobacter sp. & Glycine max & $\mathrm{Cd}$ & Rojjanateeranaj et al. (2017) \\
\hline 2. & Bacillus cereus & Vetiveria zizanioides & $\mathrm{Cr} / \mathrm{Fe}$ & Nayak et al. (2018) \\
\hline 3. & Chaetomium cupreum & Miscanthus sinensis & $\mathrm{Al}$ & Haruma et al. (2019) \\
\hline 4. & Cupriavidus basilensis & Pteris vitta ta & As & Yang et al. (2020) \\
\hline 5. & Enterobacter sp. strain EG16 & Hibiscus cannabinus & $\mathrm{Cd} / \mathrm{Fe}$ & Chen et al. (2017) \\
\hline 6. & Mesorhizobium loti HZ76 & Robinia pseudoacacia & $\mathrm{Pb} / \mathrm{Zn}$ & Fan et al. (2018) \\
\hline 7. & Microbacterium arborescens & Leptochloa fusca & $\mathrm{U} / \mathrm{Pb}$ & Ahsan et al. (2017) \\
\hline 8. & Pseudomonas libanensis & Helianthus annuus & $\mathrm{Ni}$ & Ma et al. (2019) \\
\hline 9. & Pseudomonas fuorescens & Trifolium repens & $\mathrm{Sb}$ & Daryabeigi et al. (2020) \\
\hline 10. & Streptomyces sp. & Salix dasyclados & $\mathrm{Zn} / \mathrm{Cd} / \mathrm{Pb}$ & Zloch et al. (2017) \\
\hline
\end{tabular}


tolerance of Acacia mangium. Incorporation of Brassica juncea plants with Eisenia fetida earthworm enhances significantly the detoxification efficiency of Cd. Addition of vermicompost using Ensenia Andrei to HMcontaminated soil increases the ability of black oat (Avena strigosa Schreb) plants to remove $\mathrm{Cd}, \mathrm{Cr}$ and $\mathrm{Pb}$. Various plant growth promoting bacteria (PGRB) assisted phytoremediation also enlisted in Table 2.

The strategies used to improve heavy metal phytoremediation, including genetic engineering, microbeassisted, and chelate- assisted phytoremediation, are illustrated in Fig. 2.
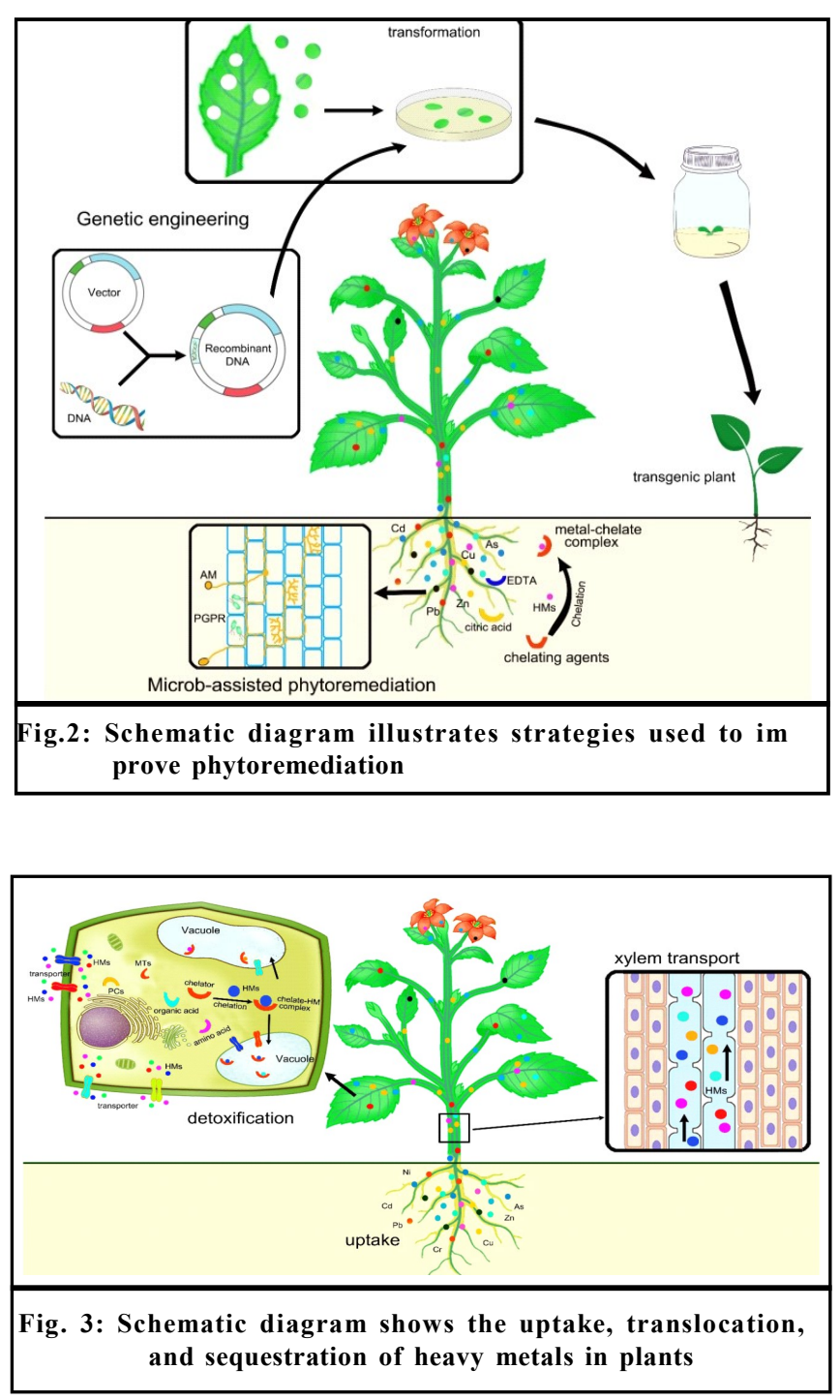

Future prospects and research needs:

Phytoremediation is one of the most promising techniques for the eco-rehabilitation of polluted sites, but further investigations and research are also necessary to enhance our knowledge inefficient phytoremediation of HMs. To avoid any failure during field cultures, it has become an essential requirement to tend toward future ways clarify mechanisms, metabolites and genes using latest techniques. These methods can aid in defining new metabolites and trails implicated in stabilization or extraction of HMs by hyper-accumulator plants. Utilization of hyper-accumulator shrubs and plants to remove HMs from soil requires novel strategies for its progress. This can be accomplished either by finding and valorising a vast diversity of new hyper-accumulator species or by genetic engineering. Multiplication and intensification of hyper-accumulator plants with higher translocation rates; high green biomass; or depth root system provide research about phenotypic differences between tolerant plants. Overexpression of foreign genes in non-tolerant plants for HMs depollution of soil is practicable. Although several plants and shrubs were established to clean up HMs through genetic engineering, no perfect model can be established for HMs detoxification until the obtainability of whole genome data is certified. Urgent works about the role of plant hormone such as IAA, GA cytokine were also needed to understand their role to increase potential of HMs detoxification plants. Plant-microorganism interaction (bacteria, fungi) was also an effective approach to uptake and translocation of HMs in plants. These approaches can aid in discovering novel metabolites and trails contributed in degradation of contaminants through plantmicroorganism interactions Mishra I, Arora NK (2019). An additional advance technique is the study of hologenome of the microorganism of plants which could be applied in manipulation of microbial niches to increase resistance against HMs contamination Mueller UG, Sachs JL (2015). Nano remediation is a novel technology assisted by microbial cells integration to enhance remediation process more effectiveness to removing HMs from high contaminated soils Song et al. (2019) and Zhu et al. (2019). However, the relation between the molecular approaches of phytoremediation and nanoparticles needs to be clearly elucidated to expand the prospect of polluted soil remediation.

\section{REFERENCES}

Abdelkrim, S., Jebara, S.H., Saadani, O., Chiboub, M., Abid, G., Mannai, K. and Jebara, M. (2019). Heavy metal accumulation in Lathyrus sativus growing in contaminated soils and identifcation of symbiotic 
resistant bacteria. Arch Microbiol., 201:107-121.

Ahsan, M.T., Najam-ul-haq, M., Idrees, M., Ullah, I. and Afzal, M. (2017). Bacterial endophytes enhance phytostabilization in soils contaminated with uranium and lead. Inter. J. Phytorem., 19 : 937-946.

Ashraf, M., Ozturk, M. and Ahmad, M.S.A. (2010). Toxins and their phytoremediation. In: Ashraf M, Ozturk M, Ahmad MSA(eds) Plant adaptation and phytoremediation. Springer, Berlin, pp. 1-32.

Banasova, V., Horak, O., Nadubinska, M., Ciamporova, M. and Lichtscheidl, I. (2008). Heavy metal content in Thlaspi caerulescens J.C. Presl growing on metalliferous and non-metalliferous soils in Central Slovakia. Intern. J. Environ. Pollut., 33 : 133-145.

Bankaji, I., Caçador, I. and Sleimi, N. (2015). Physiological and biochemical responses of Suaeda fruticosa to cadmium and copper stresses: growth, nutrient uptake, antioxidant enzymes, phytochelatin, and glutathione levels. Environ. Sci. Pollut. Res., 22: 13058-13069.

Baumann, A. (1885). Das Verhalten von Zinksatzengegen Pflanzen und im Boden. Landwirtsch. Vers.-Statn., $31: 1-53$.

Berken, A., Mulholland, M. M., Leduc, D. L. and Terry, N. (2002). Genetic engineering of plants to enhance selenium phytoremediation. Crit. Rev. Plant Sci., 21: 567-582.

Brewer, E. P., Saunders, J. A., Angle, J. S., Chaney, R. L. and Mcintosh, M.S. (1999). Somatic hybridization between the zinc accumulator Thlaspi caerulescens and Brassica napus. Theor. Appl. Genet., 99: 761771.

Byers, H.G. (1935). Selenium occurrence in certain soils in the United States, with a discussion of the related topics. US Dept. Agric. Technol. Bull. 482: 1-47.

Carreras, H.A., Wannaz, E.D., Perez, C.A. and Pignata, M.L. (2005). The role of urban air pollutants on the performance of heavy metal accumulation in Usnea amblyoclada. Environ. Res., 97 : 50-57.

Chen, Y., Yang, W., Chao, Y., Wang, S., Tang, Y.T. and Qiu, R.L. (2017). Metaltolerant Enterobacter sp. strain EG16 enhanced phytoremediation using Hibiscus cannabinus via siderophore-mediated plant growth promotion under metal contamination. Plant Soil, 413 : 203-216.

Daryabeigi Zand, A,. Tabrizi, A.M. and Heir, A.V. (2020). The influence of association of plant growth-promoting rhizobacteria and zero-valent iron nanoparticles on removal of antimony from soil by Trifolium repens. Environ. Sci. Pollut. Res., 27 : 42815-42829.

Das, N., Bhattacharya, S. and Maiti, M. K. (2016). Enhanced cadmium accumulation and tolerance in transgenic tobacco overexpressing rice metal.

Demarco, C.F., Afonso, T.F., Pieniz, S., Quadro, M.S., Camargo, F.A.O. and Andreazza, R. (2018). In situ phytoremediation characterization of heavy metals promoted by Hydrocotyle ranunculoides at Santa Bárbara stream, an anthropogenic polluted site in southern of Brazil. Environ. Sci. Pollut. Res., 25: 28312-28321.

Eissa, M.A. and Abeed, A.H.A. (2019). Growth and biochemical changes in quail bush (Atriplex lentiformis (Torr.) S.Wats) under Cd stress. Environ. Sci. Pollut. Res., 26 : 628-635.

Fan, M., Xiao, X., Guo, Y., Zhang, J., Wang, E., Chen, W., Lin, Y. and Wei, G. (2018). Enhanced phytoremediation of Robinia pseudoacacia in heavy metal-contaminated soils with rhizobia and the associated bacterial community structure and function. Chemosphere, 197 : 729-740.

Fernández San Juan, M.R., Albornoz, C.B., Larsen, K. and Najl, R. (2018). Bioaccumulation of heavy metals in Limnobium laevigatum and Ludwigia peploides: their phytoremediation potential in water contaminated with heavy metals. Environ. Earth Sci., 77 : 404.

Forte, J. and Mutiti, S. (2017). Phytoremediation potential of Helianthus annuus and Hydrangea paniculata in copper and leadcontaminated soil. Water Air Soil Pollut., 228 : 7.

Gerhardt, K.E., Gerwing, P. D. and Greenberg, B.M. (2017). Opinion: taking phytoremediation from proven technology to accepted practice. Plant Sci., 256 : $170-185$.

Hartman Jr., W.J. (1975). An evaluation of land treatment of municipal wastewater and physical sit- ing of facility installations. US Department of Army, Washington D.C., U.S.A.

Haruma, T., Yamaji, K., Ogawa, K., Masuya, H., Sekine, Y. and Kozai, N. (2019). Root-endophytic Chaetomium cupreum chemically enhances aluminum tolerance in Miscanthus sinensis via increasing the aluminium detoxicants, chlorogenic acid and oosporein. PLoS ONE, $14: 1-16$.

Kabeya, F.I., Pongrac, P., Lange, B., Faucon, M.P., Van Elteren, J.T., Šala, M., Šelih, V.S., Eeckhoudt, E.V. and Verbruggen, N. (2018). Tolerance and accumulation of cobalt in three species of Haumaniastrum and the 
Sridevi Tallapragada, Rajesh Lather, Vandana and Gurnam Singh

infuence of copper. Environ. Exp. Bot., 149 : 27-33.

Kalam, S.U., Naushin, F. and Khan, F.A. (2019). Long-term phytoremediating abilities of Dalbergia sissoo Roxb. (Fabaceae). SN Appl. Sci., 1 : 501.

Ko, B.G., Anderson, C.W.N., Bolan, N.S., Huh, K.Y. and Vogeler, I. (2008). Potential for the phytoremediation of arseniccontaminated mine tailings in Fiji. Aust. J. Soil Res., 46 : 493-501.

Korzeniowska, J. and Stanislawska-Glubiak, E. (2019). Phytoremediation potential of Phalaris arundinacea, Salix viminalis and Zea mays for nickel-contaminated soils. Int. J. Environ. Sci. Technol., 16:1999-2008.

Koz'min'ska, A., Wiszniewska, A., Hanus-Fajerska, E. and Muszyn'ska, E. (2018). Recent strategies of increasing metal tolerance and phytoremediation potential using genetic transformation of plants. Plant Biotechnol. Rep., 12 : 1-14.

Kozhevnikova, A.D., Seregin, I.V., Aarts, M.G.M. and Schat, H. (2020). Intraspecifc variation in zinc, cadmium and nickel hypertolerance and hyperaccumulation capacities in Noccaea caerulescens. Plant Soil, 452 :479-498.

Kramer, U. (2010). Metal hyperaccumulation in plants. Annu. Rev. Plant Biol., 61 : 517-534.

Kumar, D., Bharti, S.K., Anand, S. and Kumar, N. (2018). Bioaccumulation and biochemical responses of Vetiveria zizanioides grown under cadmium and copper stresses. Environ. Sustain., 1:133-139.

Liu, S., Yang, B., Liang, Y., Xiao, Y. and Fang, J. (2020). Prospect of phytoremediation combined with other approaches for remediation of heavy metal-polluted soils. Environ. Sci. Pollut. Res., 27:16069-16085.

Lutts, S., Lefèvre, I., Délperée, C., Kivits, S., Dechamps, C., Robledo, A. and Correal, E. (2004). Heavy metal accumulation by the halophyte species Mediterranean saltbush. J. Environ. Qual., 33:12711279.

Ma, Y., Rajkumar, M., Oliveira, R.S., Zhang, C. and Freitas, H. (2019). Potential of plant benefcial bacteria and arbuscular mycorrhizal fungi in phytoremediation of metal-contaminated saline soils. J. Hazard Mater, 379 : 120813.

Mani, D. and Kumar, C. (2014). Biotechnological advances in bioremediation of heavy metals contaminated ecosystems: an overview with special reference to phytoremediation. Int. J. Environ. Sci. Technol., 11: 843-872.

Marques, A. P., Rangel, A.O. and Castro, P. M. (2009).
Remediation of heavy metal contaminated soils: phytoremediation as a potentially promising cleanup technology. Crit. Rev. Env. Sci. Technol., 39 : 622-654.

Minguzzi, C. and Vergnano, O. (1948). Il contento di nichel nelliceneri di Alyssum bertlonii Desv. Atti della Società Toscana di Scienze Naturali. Mem. Ser. A. 55 : 49-77.

Mishra, I. and Arora, N.K. (2019) Rhizoremediation: A Sustainable approach to improve the quality and productivity of polluted soils. In: Arora NK, Kumar $\mathrm{N}$ (eds) Phyto and Rhizo remediation, microorganisms for sustainability. Springer, Berlin, pp. 33-66.

Mondal, N.K. and Nayek, P. (2020). Hexavalent chromium accumulation kinetics and physiological responses exhibited by Eichhornia sp. and Pistia sp. Int. J. Environ. Sci. Technol., 17:139.

Mueller, U.G. and Sachs, J.L. (2015). Engineering microbiomes to improve plant and animal health. Trends. Microbiol., 23 : 606-617.

Nayak, A.K., Panda, S.S., Basu, A. and Dhal, N.K. (2018). Enhancement of toxic $\mathrm{Cr}(\mathrm{VI}), \mathrm{Fe}$, and other heavy metals phytoremediation by the synergistic combination of native Bacillus cereus strain and Vetiveria zizanioides L. Int, J. Phytorem., 20 : 682 691.

Nedjimi, B. (2020). Germination characteristics of Peganum harmala L. (Nitrariaceae) subjected to heavy metals: implications for the use in polluted dryland restoration. Int. J. Environ. Sci. Technol., 17 : 21132122.

Nehnevajova, E., Herzig, R., Federer, G., Erismann, K.-H. and Schwitzguébel, J. P. (2007). Chemical mutagenesis-a promising technique to increase metal concentration and extraction in sunflowers. Int. J. Phytoremediat., 9: 149-165.

Pan, P., Lei, M., Qiao, P., Zhou, G., Wan, X. and Chen, T. (2019). Potential of indigenous plant species for phytoremediation of metal (loid)-contaminated soil in the Baoshan mining area, China. Environ. Sci. Pollut. Res., 26 : 23583-23592.

Pilon-Smith, E. (2005). Phytoremediation: Annual Rev. Plant Biol., 56 : 15-39.

Rai, P.K., Kim, K.H., Lee, S.S. and Lee, J.H. (2020). Molecular mechanisms in phytoremediation of environmental contaminants and prospects of engineered transgenic plants/microbes. Sci. Total Environ., 705 $: 135858$. 
Rascio, W. (1977). Metal accumulation by some plants growing on Zn mine deposits. Oikos, 29 : 250-253.

Robinson, B.H., Brooks, R.R., Howes, A.W., Kirkman, J.H. and Gregg, P.E.H. (1997). The potential of the high biomass nickel hyperaccumulator Berkheya coddii for phytoremediation and phytomining. J. Geochem. Explor., 60 : 115-126.

Rojjanateeranaj, P., Sangthong, C. and Prapagdee, B. (2017). Enhanced cadmium phytoremediation of Glycine $\max$ L. through bioaugmentation of cadmiumresistant bacteria assisted by biostimulation. Chemosphere, 185 : 764-771.

Santana, K.B., de Almeida, A.F., Souza, V.L., Mangabeira, P.A.O., Silva, D.C., Gomes, F.P., Dutruch, L. and Loguercio, L.L. (2012). Physiological analyses of Genipa americana L. reveals a tree with ability a phytostabilizer and rhizoflterer of chromium ions for phytoremediation of polluted watersheds. Environ. Exp. Bot., 80 : 35-42.

Sarwar, N., Malhi, S. S., Zia, M. H., Naeem, A., Bibi, S. and Farid, G. (2010). Role of mineral nutrition in minimizing cadmium accumulation by plants. J. Sci. Food Agric. 90 : $925-937$.

Shabir, R., Abbas, G., Saqib, M., Shahid, M., Shah, G.M., Akram, M., Niazi, N.K., Naeem, M.A., Hussain, M., Ashraf, F. (2018). Cadmium tolerance and phytoremediation potential of acacia (Acacia nilotica L.) under salinity stress. Int. J. Phytorem., 20 : 739-746.

Solanki, P., Narayan, M., Rabha, A.K. and Srivastava, R.K. (2018). Assessment of cadmium scavenging potential of Canna indica L. Bull. Environ. Contam. Toxicol., 101 : 446-450.

Song, B., Xu, P., Chen, M., Tang, W., Zeng, G., Gong, J., Zhang, P. and Ye, S. (2019). Using nanomaterials to facilitate the phytoremediation of contaminated soil. Crit. Rev.
Environ. Sci. Technol., 49 : 791-824.

Tian, J.L., Zhu, H.T., Yang, Y.A. and He, Y.K. (2004). Organic mercury tolerance, absorption and transformation in Spartina plants. J. Plant Physiol. Mol. Biol., 30 : 577-582.

Wang, J., Zhao, F., Meharg, A.A., Raab, A., Feldmann, J. and McGrath, P.S. (2002). Mechanisms of arsenic hyperaccumulation in Pteris vittata. Uptake kinetics, interactions with phosphate, and arsenic speciation. Plant Physiol., 130 : 1552-1561.

Wang, Y., Gu, C., Bai, S., Sun, Z., Zhu, T., Zhu, X., Grit, D.H. and Tembrock, L.R. (2016). Cadmium accumulation and tolerance of Lagerstroemia indica and Lagerstroemia fauriei (Lythracaeae) seedlings for phytoremediation applications. Inter. J. Phytoremediation, 18 : 1104-1112.

Wei, S., Wang, S., Li, Y. and Zhu, J. (2013). Root system responses of hyperaccumulator Solanum nigrum L. to Cd. J. Soils Sediments., 13 : 1069-1074.

Yang, C., Ho, Y.N., Makita, R., Inoue, C. and Chien, M.F. (2020). Cupriavidus basilensis strain r507, a toxic arsenic phytoextraction facilitator, potentiates the arsenic accumulation by Pteris vittata. Ecotoxicol. Environ. Saf., 190 : 110075.

Zhu, Y., Xu, F., Liu, Q., Chen, M., Liu, X., Wang, Y., Sun, Y. and Zhang, L. (2019). Nanomaterials and plants: positive efects, toxicity and the remediation of metal and metalloid pollution in soil. Sci. Total Environ., 662 : $414-421$.

Zloch, M., Kowalkowski, T., Tyburski, J. and Hrynkiewicz, K. (2017). Modeling of phytoextraction efciency of microbially stimulated Salix dasyclados L. in the soils with diferent speciation of heavy metals. Int. J. Phytorem., 19 : 1150-1164.

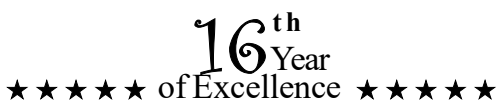

